\title{
Süt Sığırcılığı İşletmelerinde Yem Tedarikçi ve Süt Alıcı Tercihlerinin Belirlenmesi: İzmir ve Manisa Örneği
}

\section{Duran GÜLER ${ }^{* 1}$ (D) Gamze SANER ${ }^{1}$ (iD)}

\author{
${ }^{1}$ Ege Üniversitesi, Ziraat Fakültesi, Tarım Ekonomisi Bölümü, 35100, Izmir
}

Öz: Süt sığırcılığı işletmeleri açısından yem tedariği ve süt satışı tercihleri önemli kararladır. Bu çalışmanın temel amacı İzmir ve Manisa illerinde yer alan süt sığırcılığı işletmelerinde yem tedarikçi ve süt alıcı tercihlerinin belirlenmesidir. Bu amaç doğrultusunda İzmir ilinin Ödemiş ilçesinde 117 üretici ve Manisa ilinin Salihli illçesinde 30 üreticiyle yüz yüze anket yapılmıştır. Üreticilerin yem tedarikçi ve süt alıcı tercihlerinin belirlenmesinde Analitik Hiyerarşi Süreci (AHS) yönteminden yararlanılmıştır. Üreticilerin yem tedarikçi tercihi kalite, fiyat ve ödeme esnekliği kriterleri çerçevesinde değerlendirilmiştir. Süt alıcı tercihinde ise fiyat, ödeme süresi ve süt alım miktarı kriterleri esas alınmışır. Araştırma sonuçları üreticilerin yem tedariğinde en fazla yem kalitesine önem verdiklerini göstermiştir. Bu açıdan değerlendirildiğinde mandıralar en uygun yem tedarikçisi konumundadırlar. Süt satışında ise süt alıcının alım miktarııı en önemli kriter olduğu ve sütün fiyat, ödeme süresi ve alım miktarı açısından en iyi alternatif olan kooperatife satılması gerektiği belirlenmiştir. Üretici tercihlerinin tedarikçi ve alııı seçimleriyle uyumlu olması büyük oranda onların finansal sermayesinin yeterliliğine bağlıdır. Bu nedenle süt sı̆̆ırcılığı işletmelerine sağlanan finansal desteklerin artırııması önem taşımaktadır.

\section{Anahtar Kelimeler: Tarım işletmeciliği, hayvancılık, Analitik Hiyerarşi Süreci, karar verme}

\section{Determination of Feed Supplier and Milk Buyer Preferences in Dairy Farms: The Cases of Izmir and Manisa}

\begin{abstract}
Feed supply and milk sale preferences are important decisions in terms of dairy farms. The main purpose of this research is to determine feed supplier and milk buyer preferences in dairy farms in Izmir and Manisa provinces. To this purpose, face-to-face surveys were conducted with 117 producers in Odemis district of Izmir province and 30 producers in Salihli district of Manisa province. Analytical Hierarchy Process (AHP) was used to determine supplier and buyer preferences of the producers. The feed supplier preference of the producers has been evaluated within the framework of quality, price and payment flexibility. As for buyer preference, it is based on price, payment period and milk purchase amount. The results of the research show that the producers attach particular importance to feed quality. In this respect, dairies are the most suitable feed suppliers. It was determined that the purchase amount of the milk buyer is the most important criteria in milk sales, and the milk should be sold to the cooperative, which is the best alternative in terms of price, payment period and purchase amount. The compatibility of producer preferences with supplier and buyer selections largely depend on the adequacy of their financial capital. It is important to increase financial supports for dairy farms.
\end{abstract}

Keywords: Farm management, livestock, Analytical Hierarchy Process, decision making

\section{GiRiş}

Günümüzde tedarik zinciri kavramının gelişmesine bağlı olarak alıcı-tedarikçi ilişkileri, kısa süreli ilişkilerin kurulduğu rekabete dayalı alım-satımların gerçekleştirildiği ilişkilerden çok daha öteye, uzun süreli ilişkilerin kurulduğu iş ortaklıkları olarak nitelendirilmeye başlanmıştır. Dolayısıyla bu tür uzun süreli ilişkilerin kurulacağı tedarikçilerin değerlendirilmesi ve seçim kararı yöneticiler için kritik bir karar süreci olarak ele alınmalıdır (Türer ve ark., 2009). Tedarikçiden sağlanan hammaddenin kalitesi ve maliyeti, tedarikçinin teslim tarihi, değişen taleplere karşı tedarikçi esnekliği ve tedarikçinin sağladığı hizmetler, üretilen üründeki müşteri memnuniyetine etki eden önemli faktörlerdir (Özçakar ve Demir, 2011).

Süt sığırcılığı işletmeleri açısından da tedarikçi-alıcı ilişkisi ve bu ilişkiye bağı tercihler oldukça önemlidir. Literatürde farklı alanlarda tedarikçi tercihini inceleyen çalışmalar bulunmaktadır (Noci, 1997; Ghodsypour ve O'Brien, 1998; Masella ve Rangone, 2000; Dağdeviren ve Eren, 2001; Handfield ve ark., 2002; Kokangul ve Susuz, 2009; Demir, 2010; Büyüközkan ve Çifçi, 2011; Nie, 2012; Beikkhakhian ve ark., 2015; Cheaitou ve Khan, 2015; Hamdan ve Cheaitou, 2015; Jeng, 2015; Kannan ve ark., 2015; Sarı ve Timor, 2015). Noci (1997) çalışmasında çevresel performansa dayalı tedarikçi seçimine yönelik yöntemler önermiştir. Çevresel performansı ise 'yeşil' yeterlilik, mevcut çevresel etkinlik, tedarikçinin 'yeşil' imajı ve net yaşam döngüsü maliyeti kriterleri çerçevesinde değerlendirmiştir. Ghodsypour ve O'Brien (1998) tedarikçi seçimine yönelik geliştirdikleri karar destek sisteminde tedarikçileri maliyet, kalite, hizmet ve kapasite kriterleri çerçevesinde değerlendirmişler ve alıcı firmanın daha düşük fiyatlı ve daha iyi hizmetle ürün sunan tedarikçiden ziyade en kaliteli ürünü sunan tedarikçiyi tercih ettiğini saptamışlardır. Dağdeviren ve Eren (2001) çalışmalarında tedarikçi tercihini kalite, performans, maliyet ve teknoloji kriterleri çerçevesinde değerlendirmişlerdir. Kokangul ve

Sorumlu Yazar: duran.quler@ege.edu.tr. Bu çalışma doktora tez ürünüdür.

Geliş Tarihi: 3 Nisan 2020

Kabul Tarihi: 18 Kasım 2020 
Süt Sığırcılığı Işletmelerinde Yem Tedarikçi ve Süt Alıcı Tercihlerinin Belirlenmesi: Izmir ve Manisa Örneği

Susuz (2009) çalışmalarında tedarikçi seçimini satın alma ve kalite temel kriterlerine bağlı 24 alt kriter çerçevesinde değerlendirmişlerdir. Hamdan ve Cheaitou (2015) 'yeşil' tedarikçi seçimine yönelik model önerilerini 'yeşil' kriterler (çevresel yönetim sistemleri, 'yeşil' imaj, ekolojik tasarım ve çevresel hedeflere yönelik personel eğitimi) ve geleneksel kriterler (kalite, ürün maliyeti, teslim süresi, finansal istikrar ve geçmiş performans) çerçevesinde geliştirmişlerdir. Sarı ve Timor (2015) otomotiv sektöründeki bir firmanın tedarikçi seçimi için önerdikleri modelde kalite, sevkiyat, fiyat, çevre, finansal durum, yönetim ve çalışma koşulları olmak üzere yedi ana kriteri esas almışlardır. Ancak literatürde süt sığırcılı̆ıında yem tedarikçisi ve süt alıcı tercihini inceleyen herhangi bir çalışmaya rastlanmamıştır. Yapılan araştırmalar süt sığırcılığı işletmelerinde yem masraflarının toplam değişken masraflar içerisinde en fazla paya sahip olan masraf unsuru olduğunu ortaya koymaktadır. Ayrıca bu işletmelerde süt geliri de en temel gelir kaynağıdır (Güler ve Saner, 2017). Bu nedenle süt sığırcılığı işletmelerinde yem tedarikçi ve süt alıcı tercihlerinin incelenmesi gerek üretici açısından, gerekse süt sığırcılığı faaliyetinin sürdürülebilirliği açısından son derece önem taşımaktadır.

Bu çalışmada süt sığırcılığı işletmelerinde yem tedarikçi ve süt alııı tercihlerinin belirlenmesi amaçlanmıştır. Bu amaç çerçevesinde yem tedariğinde kalite, fiyat ve ödeme esnekliği kriterleri; süt satışında ise alıcıların süt alım miktarı, ödeme süresi ve fiyat kriterleri göz önünde bulundurulmuştur.

\section{MATERYAL VE YÖNTEM}

Çalışmanın ana materyalini birincil veriler oluşturmakta olup, bu veriler İzmir ili Ödemiş ilçesi ile Manisa ili Salihli ilçesinde süt sığırcılığı yapan üreticilerle yüz yüze yapılan anketlerden elde edilmiştir.

Araştırma kapsamı belirlenirken bu illerde ve ilçelerde üretilen süt üretim miktarı esas alınmıştır. Nitekim 2018 yılında Türkiye'de üretilen inek sütünün \%5.84'ü İzmir'de ve \%1.32'si Manisa'da üretilmiştir. Ödemiş ilçesinde İzmir'de üretilen sütün \%33.07'si, Salihli ilçesinde ise Manisa'da üretilen sütün \%18.64'ü üretilmiştir (Anonim, 2020). İzmir ili Damızık Sığır Yetiştiricileri Birliği'nden (DSYB) alınan verilere göre Ödemiş ilçesinde i̇zmir Damızlık Sı̆̆ır Yetiştiricileri Birliği'ne kayıtlı olan; Manisa ili Salihli ilçesinde de Manisa Damızlık Sığır Yetiştiricileri Birliği'ne kayıtlı olan ve süt teslimi yapan üretici sayısı ana kitle olarak kabul edilmiş olup, örnek hacmi buna göre hesaplanmıştır. Örnek hacmi hesaplanırken oransal örnek hacmi formülünden yararlanılmıştır (Newbold, 1995).

$$
n=\frac{N p(1-p)}{(N-1) \sigma_{p x}^{2}+p(1-p)}
$$

Formülde;

$\mathrm{n}=$ Örnek hacmi

$\mathrm{N}=$ Toplam süt sığırcılığı yapan üretici sayısı

$\mathrm{p}=$ Örneğe girecek üreticilerin oranı

$$
\sigma^{2} p x=\text { Oranın varyansıdır. }
$$

Burada $p$ değeri, üzerinde çalı̧ılan özelliğin ana kitledeki oranı veya rastlanma olasılığıdır. Hesaplamada, maksimum örnek hacmine ulaşılmak istendiğinden, p: 0.50 ve (1-p): 0.50 olarak alınmıştır. Ödemiş ilçesinde İzmir Damızlık Sığır Yetiştiricileri Birliği'ne kayıtlı olan ve süt teslimi yapan üretici sayısı 2,534, Manisa ili Salihli ilçesinde Manisa Damızlık Sığır Yetiştiricileri Birliği'ne kayıtlı olan ve süt teslimi yapan üretici sayısı $641^{\prime}$ dir. Toplam 3,175 üretici ana kitle olarak kabul edilmiştir. Buna göre görüşülmesi gereken üretici sayısı \%95 güven aralığı, \%8 hata payı ile 143 üretici olarak hesaplanmıştır. Verilerin analizinde gruplar arası karşılaştırmalarda kullanılabilecek olası parametrik testler için Salihli'de yapılması gereken anket sayısının en az 30 olmasına karar verilmiştir ve örneklem sayısı 4 artırılarak 147 'ye yükseltilmiştir. Bu değer ilçedeki üretici sayılarına oranlandığında Ödemiş'te 117, Salihli'de ise 30 üretici ile görüşülmesine karar verilmiştir. Bulunan değerler seçilen ilçelerdeki toplam üretici sayısına oranlanarak her köyde kaç üretici ile görüşüleceği belirlenmiştir. Bu köylerden tesadüfi olarak seçilen üreticilerle yüz yüze görüşme yoluyla anket formları doldurulmuştur. DSYB'ne asıl üyelik için asgari 5 baş ineğe sahip olma koşulu bulunmaktadır. Bu nedenle işletme gruplarında 5 ve 5 'in üzerinde ineğe sahip işletmeler yer almıştır. Bu işletmeler inek sayılarına göre 515 baş, $16-25$ baş, 26-40 baş ve 41 baş ve üzeri olmak üzere dört gruba ayrılmışırı. Ancak çalışmada yem tedarikçi ve süt alıcı tercihleri il yada işletme gruplamasına yer vermeksizin işletmelerin geneli üzerinden analiz edilmiştir.

Çalışmada yem tedarikçi ve süt alıcı tercihlerinin belirlenmesinde Analitik Hiyerarşi Süreci (AHP) yönteminden yararlanılmıştır. Saaty (1980) tarafından geliştirilen AHP, karar verme problemlerinin çözümü için kullanılan bir yöntemdir. Bu yöntem birden çok kritere bağlı öznel yönetim girdilerine dayanan faydalı bir ölçüm modelidir. Bu girdiler olası alternatiflerin her birini değerlendirmek için kullanılan puanlara dönüştürülmektedir. AHP işletmecilikte karmaşık yapıdaki çok kriterli kararların oluşturulmasında başarısı kanıtlanmış güçlü bir yönetim bilimi aracıdır (Handfield ve ark., 2002).

$\mathrm{Bu}$ yöntem karar noktalarının önem derecelerini ikili karşılaştırmalar yoluyla ölçme teorisine dayanmaktadır. 
Karşılaştırmalar bir kararın belirli bir niteliğe göre diğer kararlardan ne kadar baskın olduğunu gösteren mutlak yargı ölçeği kullanılarak yapılmaktadır. Öncelikleri sistemli bir şekilde belirlenmiş bir karar alabilmek için aşağıdaki adımlar izlenmelidir (Saaty, 2008).

- Sorun tanımlanmalı ve istenilen bilgi belirlenmelidir.

- Karar amacının en üstte yer aldığı ve bu amaca yönelik alt unsurlara bağı kriterler ile alternatiflerin bulunduğu bir karar hiyeraşisi oluşturulmalıdır.

- Kriterler arası ikili karşılaştırma matrisi oluşturulmalıdır.

- Karşılaştırma matrisi aracılığıyla kriterlerin birbirlerine göre seviyeleri ve bütün içerisindeki önem ağırlıkları belirlenmelidir.

Kriterlere ilişkin önem ölçeği ise Çizelge 1'deki gibi tanımlanmaktadır (Saaty, 1980)

Bu çalışmada üreticilerin yem tedarikçi tercihi belirlenirken tedarikçiler arasında yer alan kooperatif, birlik, tüccar ve mandıralar kalite, fiyat ve ödeme esnekliği kriterleri çerçevesinde değerlendirilmiştir (Şekil 1).

Çizelge 1. Kriterlere ilişkin önem ölçeği
GÜLER D, SANER G

Bununla birlikte üreticilerin süt alıcı tercihi belirlenirken alıcılar arasında yer alan kooperatif, birlik, aracı, mandıra ve tüketiciler (doğrudan satış) alım miktarı, ödeme süresi ve fiyat kriterleri çerçevesinde değerlendirilmiştir (Şekil 2).

\section{BULGULAR}

\section{Yem tedarikçi tercihinin belirlenmesi}

Analitik Hiyerarşi Sürecinden yararlanılarak üreticilerin yem tedarikçi ve süt alıcı tercihlerinin belirlendiği bu bölümde öncelikle işletmelerin mevcut yem tedarikçileri ve mevcut süt alıcıları ortaya konulmuştur. Buna göre tüccarlar işletmelere en fazla oranda (\%37.75) yem sağlayan tedarikçilerdir. Tüccarları sırasıyla mandıralar (\%31.13), kooperatifler (\%23.18), fabrikalar (\%5.96) ve birlikler (\%1.99) izlemektedir. Salihli'deki üreticilerin yem tedarikçilerinin dağılımında tüccarlar önemli bir paya (\%67.74) sahiptir (Çizelge 2).

Mevcut yem tedarikçilerinin dağılımı işletme büyüklüklerine göre değerlendirildiğinde büyük ölçekli işletmelerde (4. grup) ilk sırayı mandıralar almakta iken, diğer gruplarda tüccarlar ilk sırada yer almaktadır (Çizelge 3).

\begin{tabular}{ll}
\hline Önem Değerleri & Açıklama \\
\hline 1 & Her iki kriterin eşit öneme sahip olması durumu \\
3 & Bir kriterin diğer kriterden daha önemli olması durumu \\
5 & Bir kriterin diğer kriterden çok önemli olması durumu \\
7 & Bir kriterin diğer kritere göre çok güçlü öneme sahip olması durumu \\
9 & Bir kriterin diğer kritere göre mutlak üstün bir öneme sahip olması durumu \\
\hline
\end{tabular}

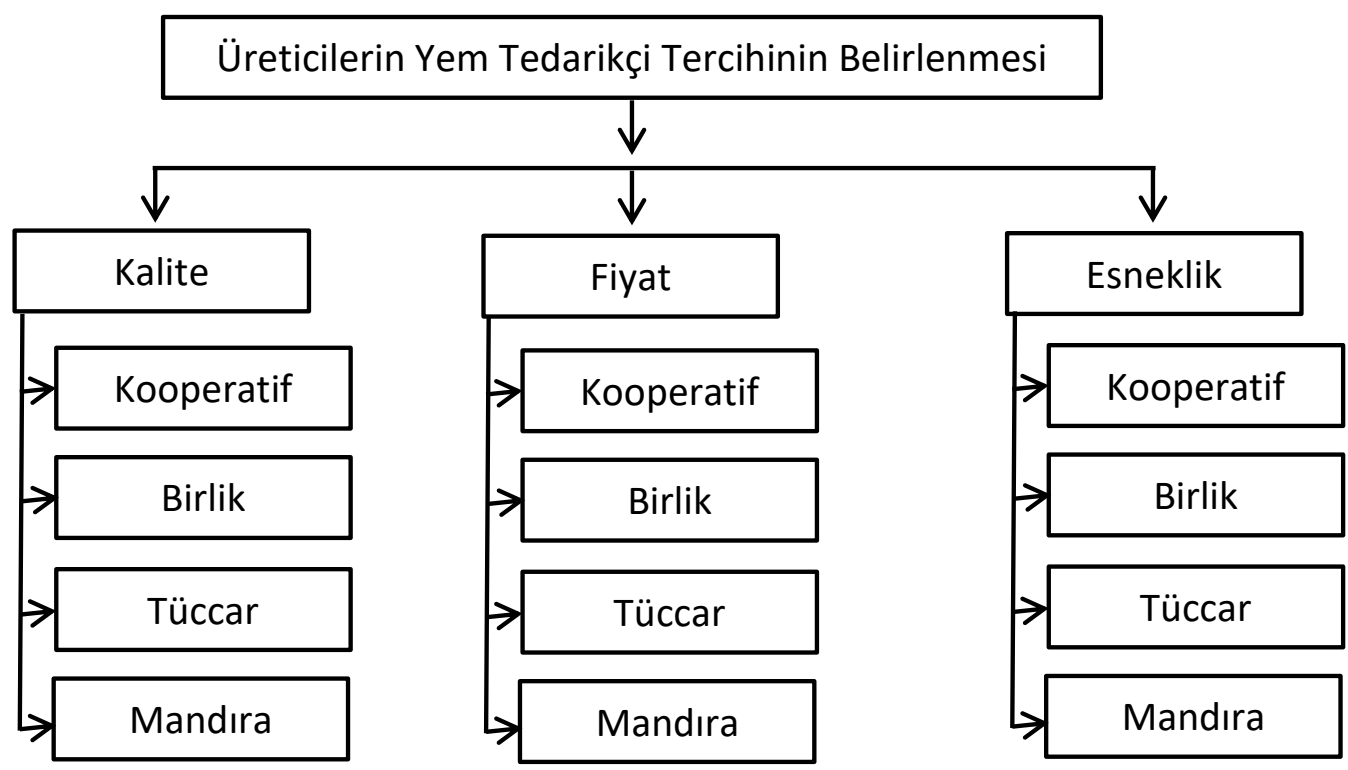

Şekil 1. Yem tedarikçi tercihinin belirlenmesine ilişkin hiyerarşi 


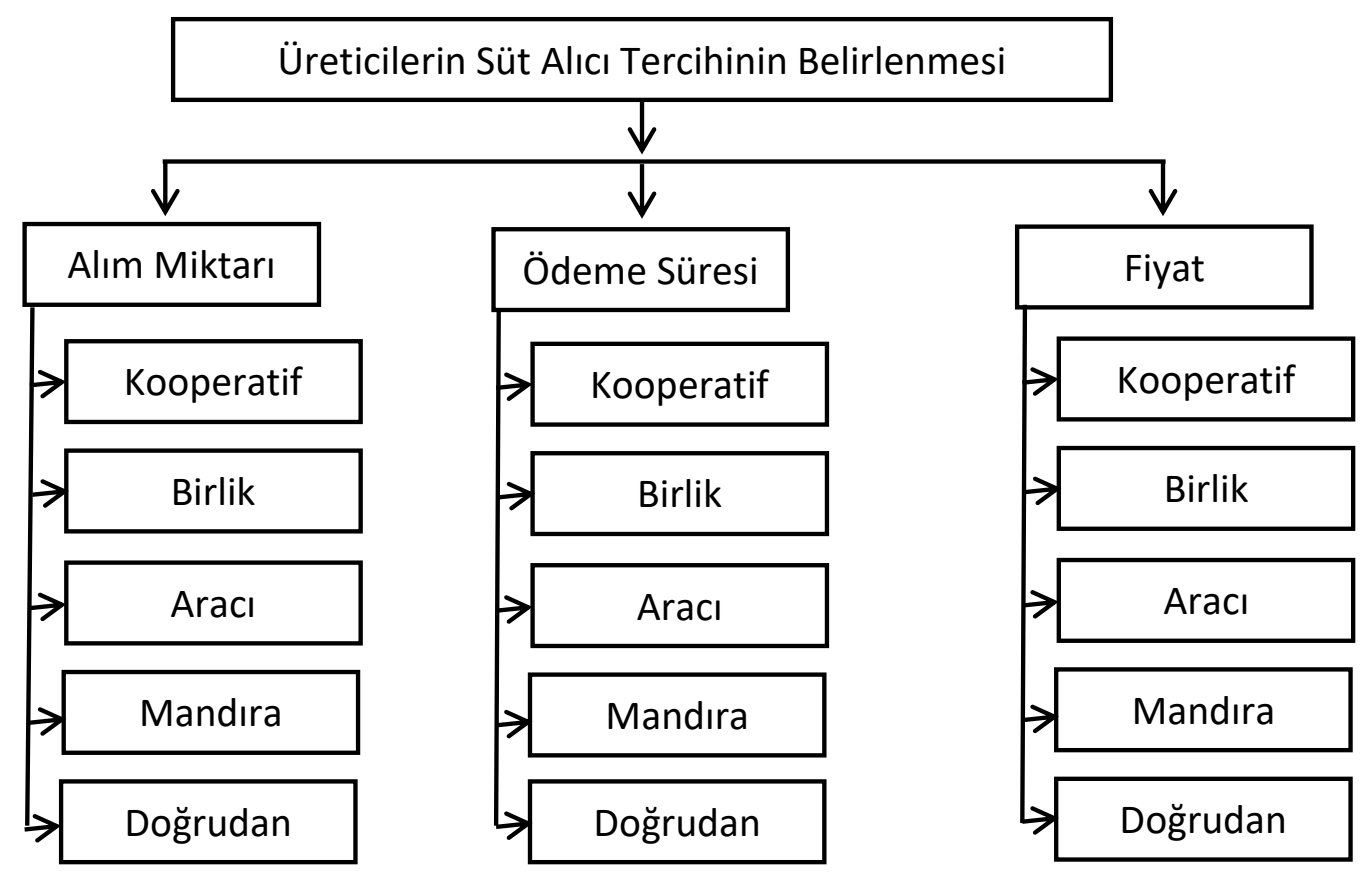

Şekil 2. Süt alıcı tercihinin belirlenmesine ilişkin hiyerarşi

Çizelge 2. İşletmelerin yem tedarikçilerinin dağılımı

\begin{tabular}{|c|c|c|c|c|c|c|}
\hline \multirow{2}{*}{ Yem Tedarikçi } & \multicolumn{2}{|c|}{ Ödemiş (117) } & \multicolumn{2}{|c|}{ Salihli (30) } & \multicolumn{2}{|c|}{ Genel (147) } \\
\hline & Sayı & $\%$ & Sayı & $\%$ & Sayı & $\%$ \\
\hline Tüccar & 36 & 30.00 & 21 & 67.74 & 57 & 37.75 \\
\hline Mandıra & 42 & 35.00 & 5 & 16.13 & 47 & 31.13 \\
\hline Kooperatif & 33 & 27.50 & 2 & 6.45 & 35 & 23.18 \\
\hline Fabrika & 6 & 5.00 & 3 & 9.68 & 9 & 5.96 \\
\hline Birlik & 3 & 2.50 & - & - & 3 & 1.99 \\
\hline
\end{tabular}

*Birden fazla yanıt alınmıştır.

Çizelge 3. İşletme büyüklüklerine göre yem tedarikçilerinin dağılımı

\begin{tabular}{|c|c|c|c|c|c|c|c|c|}
\hline \multirow{3}{*}{ Yem Tedarikçi } & \multirow{2}{*}{\multicolumn{2}{|c|}{$\begin{array}{l}\text { 1. Grup (32) } \\
\text { 5-15 Baş }\end{array}$}} & \multirow{2}{*}{\multicolumn{2}{|c|}{$\begin{array}{l}\text { 2. Grup (46) } \\
\text { 16-25 Baş }\end{array}$}} & \multirow{2}{*}{\multicolumn{2}{|c|}{$\begin{array}{l}\text { 3. Grup (36) } \\
\text { 26-40 Baş }\end{array}$}} & \multirow{2}{*}{\multicolumn{2}{|c|}{$\begin{array}{l}\text { 4. Grup (33) } \\
\geq 41 \text { Baş }\end{array}$}} \\
\hline & & & & & & & & \\
\hline & Sayı & $\%$ & Sayı & $\%$ & Sayı & $\%$ & Sayı & $\%$ \\
\hline Tüccar & 13 & 39.39 & 20 & 42.55 & 16 & 44.44 & 8 & 22.86 \\
\hline Mandıra & 13 & 39.39 & 14 & 29.79 & 10 & 27.78 & 10 & 28.57 \\
\hline Kooperatif & 5 & 15.15 & 13 & 27.66 & 8 & 22.22 & 9 & 25.71 \\
\hline Fabrika & 1 & 3.03 & - & 0.00 & 1 & 2.78 & 7 & 20.00 \\
\hline Birlik & 1 & 3.03 & - & 0.00 & 1 & 2.78 & 1 & 2.86 \\
\hline
\end{tabular}

*Birden fazla yanıt alınmıştır. 


\section{Yem tedarik kriterlerinin öncelik durumu}

Araştırmada tedarikçi tercihleri belirlenmeden önce yem tedariğinde önem taşıyan kalite, fiyat ve ödeme esnekliği kriterlerinin önceliği belirtilmiştir. Buna göre üreticilerin en fazla önem verdikleri kriterin kalite olduğu saptanmıştır. İkinci ve üçüncü önceliğe sahip kriterler ise sırasıyla fiyat ve esnekliktir (Çizelge 4). Daha önce de ifade edildiği gibi CR değerinin 0.1 'den küçük olması karar vericinin yaptığı karşılaştırmaların tutarlı olduğunu göstermektedir.

Çizelge 4. Yem tedariğinde kriterlerin öncelik sırası

\begin{tabular}{lcc}
\hline Kriter & Öncelik Ağırlığı & Sıralama \\
\hline Kalite & 0.63 & 1 \\
Fiyat & 0.26 & 2 \\
Esneklik & 0.11 & 3 \\
\hline
\end{tabular}

CR (Tutarlılık Oranı): $0.03337<0.1$

\section{Kaliteye göre yem tedarikçi tercihi}

Üreticilerin yem tedarikçi alternatifleri arasında mandıralar, kooperatifler, birlikler ve tüccarlar bulunmaktadır. Üreticilerden tedarikçiler tarafından satışı yapılan yemin kalitesinin tedarikçiler çerçevesinde değerlendirmeleri istenmiştir. Elde edilen sonuçlar mandıralardan temin edilen yemin diğer tedarikçilere göre daha kaliteli olduğunu göstermektedir (Çizelge 5). Mandıralar üreticilerden satın aldıkları sütü işleyerek ambalajlı içme sütü ve süt ürünleri üretmektedirler. Süt ürünleri sektöründe mevcut olan yüksek rekabet, mandıraların tüketici tercihlerine uygun kaliteli ürün (örneğin; yüksek yağ ve protein oranına sahip olan ürün) üretmelerini zorunlu kılmaktadır. Bu nedenle mandıralar genellikle sütünü satın aldıkları/alacakları süt sığırcılığı işletmelerinde kendi istedikleri kaliteli yemlerin tüketilmesini zorunlu kılmaktadırlar.

Çizelge 5. Kaliteye göre yem tedarikçi tercihinin öncelik sırası

\begin{tabular}{lcc}
\hline Yem Tedarikçi & Öncelik Ağırlığı & Sıralama \\
\hline Mandıra & 0.50000 & 1 \\
Kooperatif & 0.16667 & 2 \\
Birlik & 0.16667 & 2 \\
Tüccar & 0.16667 & 2 \\
\hline
\end{tabular}

CR (Tutarlılık Oranı): $0.00000<0.1$

Fiyata göre yem tedarikçi tercihi

Tedarikçiler satışını yaptıkları yemlerin fiyatları çerçevesinde değerlendirildiğinde kooperatif ve birlik, öncelik açısından ilk sırada yer almaktadırlar. Bu tedarikçileri ise sırasıyla mandıra ve tüccar izlemektedir. Kooperatif ve birlikler üretici örgütleri olarak üyelerine uygun fiyatla hizmet ve ürün sağlamayı ilke edinmişlerdir. $\mathrm{Bu}$ durum üreticilere sunulan yem fiyatlarında da görülmektedir. Mandıralar ise tüccarlara göre daha fazla sermayeye ve süt alım gücüne sahip olmanın sağladığı avantajla tüccardan daha uygun fiyatlı yem satabilmektedirler (Çizelge 6).

\begin{tabular}{lcc}
\multicolumn{3}{l}{ Çizelge 6. Fiyata göre yem tedarikçi tercihinin öncelik sırası } \\
\hline Yem Tedarikçi & Öncelik Ağırlığı & Sıralama \\
\hline Kooperatif & 0.38893 & 1 \\
Birlik & 0.38893 & 1 \\
Mandıra & 0.15345 & 2 \\
Tüccar & 0.06869 & 3 \\
\hline
\end{tabular}

CR (Tutarlılık Oranı): $0.01625<0.1$

\section{Esnekliğe göre yem tedarikçi tercihi}

Ödeme esnekliği açısından karşılaştırıldığında mandıralar tedarikçiler arasında ilk sırada yer almaktadır. Analiz sonucuna göre mandırayı ikinci sırada tüccar, üçüncü sırada ise kooperatif ve birlik izlemektedir (Çizelge 7). Aslında uygulamada bu durum değişkenlik gösterebilmektedir. İşletmeler genellikle süt satışı yaptıkları alıcılardan aynı zamanda yem tedarik etmektedirler ve yem bedeli işletmelere ödenmesi gereken süt parası (süt geliri) içinden kesintiye uğratılarak tahsil edilmektedir. Ayrıca üreticilerin süt satışı yaptıkları alıcılardan nakit avans aldıkları da bilinmektedir. Dolayısıyla yem satın alınan tedarikçilerin üreticilere sundukları ödeme esnekliği; üreticilerin tedarikçiye borcu olup olmamasıyla, borcunun ödeme süresiyle ve toplam borç miktarı ile doğrudan ilişkilidir. Ayrıca bu durum yem fiyatları için de geçerlidir. Alıcıya uzun vadeli borçlanan üreticilerin tedarik ettikleri yem fiyatları daha yüksek olabilmektedir.

Çizelge 7. Esnekliğe göre yem tedarikçi tercihinin öncelik sırası

\begin{tabular}{lcc} 
Yem Tedarikçi & Öncelik Ağırlığı & Sıralama \\
\hline Mandıra & 0.61358 & 1 \\
Tüccar & 0.25129 & 2 \\
Kooperatif & 0.06757 & 3 \\
Birlik & 0.06757 & 3 \\
\hline CR (Tutarlılık Oranı): $0.07859<0.1$ &
\end{tabular}

\section{Süt alıcı tercihinin belirlenmesi}

İşletmelerden süt alımı yapanların dağılımı değerlendirildiğinde alıcılar arasında mandıraların \%42.86 oranla ilk sırada yer aldığı belirlenmiştir. Mandıraları sırasıyla aracılar (\%27.89), kooperatifler (\%23.81), fabrikalar (\%3.40) ve birlikler (\%2.04) izlemektedir (Çizelge 8). Koç ve Uzmay (2018) tarafından Trakya Bölgesi'nde yapılan araştırmada üreticilerin \%60.2'sinin süt alıcısının kooperatifler olduğu saptanmıştır. Bu durum bölgeler arasında süt alıcı bakımından önemli düzeyde farklılıklar olabileceğini göstermektedir.

Süt alıcılar ilçelere göre değerlendirildiğinde Salihli ilçesinde aracıların \%56.67 ile ilk sırada yer aldığı tespit edilmiştir (Çizelge 8).

Mevcut süt alıcılarının dağılımı işletme büyüklüklerine göre değerlendirildiğinde bütün işletme gruplarında mandıralar ilk sırada yer almaktadır (Çizelge 9). Koç ve Uzmay'ın (2018) çalışmasında işletme büyüklüğünün (5-14, 15-29, 30-49 ve 50-99 baş) üreticilerin sütü kooperatif aracılığıyla pazarlama olasılığını etkilemediği saptanmıştır. 
Çizelge 8. İşletmelerden süt alımı yapanların dağııımı

\begin{tabular}{|c|c|c|c|c|c|c|}
\hline \multirow{2}{*}{ Süt Alıcı } & \multicolumn{2}{|c|}{ Ödemiş (117) } & \multicolumn{2}{|c|}{ Salihli (30) } & \multicolumn{2}{|c|}{ Genel (147) } \\
\hline & Sayı & $\%$ & Sayı & $\%$ & Sayı & $\%$ \\
\hline Mandıra & 57 & 48.72 & 6 & 20.00 & 63 & 42.86 \\
\hline Aracı (Tüccar) & 24 & 20.51 & 17 & 56.67 & 41 & 27.89 \\
\hline Kooperatif & 31 & 26.50 & 4 & 13.33 & 35 & 23.81 \\
\hline Fabrika & 3 & 2.56 & 2 & 6.67 & 5 & 3.40 \\
\hline Birlik & 2 & 1.71 & 1 & 0.00 & 3 & 2.04 \\
\hline
\end{tabular}

Çizelge 9. İşletme büyüklüklerine göre süt alımı yapanların dağılımı

\begin{tabular}{|c|c|c|c|}
\hline \multirow{3}{*}{ Süt Alıcı } & \multirow{2}{*}{\multicolumn{2}{|c|}{$\begin{array}{l}\text { 1. Grup (32) } \\
\text { 5-15 Baş }\end{array}$}} & \multirow{3}{*}{$\begin{array}{l}\text { 2. Grup } \\
16-25 \\
\text { Sayı }\end{array}$} \\
\hline & & & \\
\hline & Sayı & $\%$ & \\
\hline Mandıra & 16 & 48.48 & 21 \\
\hline Aracı (Tüccar) & 10 & 30.30 & 15 \\
\hline Kooperatif & 6 & 18.18 & 10 \\
\hline Fabrika & - & 0.00 & - \\
\hline Birlik & 1 & 3.03 & - \\
\hline \multicolumn{4}{|c|}{$\begin{array}{l}\text { Süt satış kriterlerinin öncelik durumu } \\
\text { Araştırmada süt satışında önem arz eden süt alım miktarı, } \\
\text { ödeme süresi ve fiyat kriterlerinin öncelikleri belirlenmiştir. } \\
\text { Buna göre süt satışında önem verilen kriterler arasında } \\
\text { öncelik bakımından süt alım miktarının ilk sırada yer aldığı } \\
\text { belirtilmiştir. Ödeme süresi ikinci, süt fiyatı ise üçüncü } \\
\text { sırada bulunmaktadır (Çizelge 10). Üreticiler için yüksek } \\
\text { fiyatla kısa sürede bedelini tahsil edebilecekleri süt satışı } \\
\text { gerçekleştirebilmek oldukça avantajlıdır. Ancak onlar } \\
\text { açısından bundan daha önemlisi ürettikleri sütün tamamını } \\
\text { satabilmeleridir. Çünkü üreticilerin sütün tamamını } \\
\text { satamamaları durumunda sütü değerlendirebilme } \\
\text { olanakları oldukça kısıtlıdır. }\end{array}$} \\
\hline \multicolumn{4}{|c|}{ Çizelge 10. Süt satış kriterlerinin öncelik sırası } \\
\hline Kriter & Öncelik & & Sıralama \\
\hline Alım Miktarı & 0.723 & & 1 \\
\hline Ödeme Süresi & 0.193 & & 2 \\
\hline Fiyat & 0.083 & & 3 \\
\hline
\end{tabular}

CR (Tutarlılık Oranı): $0.05674<0.1$

\section{Fiyata göre süt alıcı tercihi}

Üreticiler sütü kooperatif, birlik, mandıra, aracı veya doğrudan tüketiciye satmaktadırlar. Üreticilerden süt alım miktarı, fiyatı ve süt bedelini ödeme süresi bakımından alıcıları değerlendirilmeleri istenmiştir. Analiz sonucunda doğrudan satışla tüketicilerden talep edilecek fiyatın diğer alıcılara göre daha fazla olduğu belirlenmiştir. Ancak doğrudan tüketiciye satılabilecek süt miktarı, üretilen süt miktarının çok altında olduğu için doğrudan satış üreticilerin tercih edebilecekleri bir alternatif değildir. Doğrudan satışı sırasıyla kooperatif, birlik, mandıra ve aracılar izlemektedir (Çizelge 11). Bu genellemenin yanı sıra süt fiyatı üzerinde 212
3. Grup (36)

4. Grup (33)

26-40 Baş

\begin{tabular}{ccccc}
$\%$ & Sayı & $\%$ & Sayı & $\%$ \\
\hline 45.65 & 13 & 36.11 & 13 & 40.63 \\
32.61 & 10 & 27.78 & 6 & 18.75 \\
21.74 & 12 & 33.33 & 7 & 21.88 \\
0.00 & - & 0.00 & 5 & 15.63 \\
0.00 & 1 & 2.78 & 1 & 3.13 \\
\hline
\end{tabular}

satılan süt miktarının da etkisi olduğu göz önünde bulundurulmalıdır.

Süt üretim kapasitesi yüksek olan işletmelerde üreticiler herhangi bir alıcıdan piyasa fiyatının üzerinde bir fiyat talep edebilmektedir. Kooperatif ve birliklerin, mandıra ve aracılara göre süt fiyatı açısından daha avantajlı alıcılar oldukları üreticiler tarafından bilinmesine rağmen mandıra ve aracıların üreticilere avans verebilme gücü bu alıcıları üreticilerin süt alıcı tercihinde avantajlı konuma getirmektedir.

Çizelge 11. Fiyata göre süt alıcı tercihinin öncelik sırası

\begin{tabular}{lcc}
\hline Süt Alıcı & Öncelik Ağırlı̆̆ & Sıralama \\
\hline Doğrudan & 0.59444 & 1 \\
Kooperatif & 0.21273 & 2 \\
Birlik & 0.10392 & 3 \\
Mandıra & 0.04511 & 4 \\
Aracı & 0.04379 & 5 \\
\hline
\end{tabular}

CR (Tutarlılık Oranı): $0.07483<0.1$

Ödeme süresine göre süt alıcı tercihi

Süt alıcılarının neredeyse tamamı üreticilerden aldıkları sütün 15 günlük bedelini içeride tutup, 15 günü izleyen 30 . gün sonunda aylık olarak ödeme yapmaktadırlar. Sadece doğrudan tüketiciye satış yapıldığı takdirde peşin ödeme alınmaktadır. Daha önce de belirtildiği gibi bu yaygın bir uygulama olmamakla birlikte işletme ölçeği göz önüne alındığında mevcut durumda uygulanabilir bir satış alternatifi değildir. Buna rağmen ödeme süresi bakımından doğrudan satışın önceliği ilk sırada yer almaktadır (Çizelge 12). 
Çizelge 12. Ödeme süresine göre süt alıcı tercihinin öncelik sırası

\begin{tabular}{lcc}
\hline Süt Alıcı & Öncelik Ağırlığı & Sıralama \\
\hline Doğrudan & 0.69231 & 1 \\
Kooperatif & 0.07692 & 2 \\
Birlik & 0.07692 & 2 \\
Mandıra & 0.07692 & 2 \\
Aracı & 0.07692 & 2 \\
\hline
\end{tabular}

CR (Tutarlılık Oranı): $0.00000<0.1$

\section{Alım miktarına göre süt alıcı tercihi}

Doğrudan tüketiciye satış haricinde hiçbir alıcının alım miktarıyla ilgili bir kısıtı bulunmamaktadır. Eğer piyasa koşullarıyla ilgili herhangi bir aksaklık yoksa bütün alıcılar sütün tamamını satın alabilecek durumdadırlar. Buna göre doğrudan satış tercihinin önceliği son sırada yer almaktadır (Çizelge 13).

Çizelge 13. Alım miktarına göre süt alıcı tercihinin öncelik sırası

\begin{tabular}{lcc}
\hline Süt Alıcı & Öncelik Ağırlı̆̆ & Sıralama \\
\hline Kooperatif & 0.24324 & 1 \\
Birlik & 0.24324 & 1 \\
Mandıra & 0.24324 & 1 \\
Aracı & 0.24324 & 1 \\
Doğrudan & 0.02703 & 2 \\
\hline
\end{tabular}

CR (Tutarlılık Oranı): $0.00000<0.1$

\section{SONUÇ}

Araştırmada ilçeler arasında hem yem tedarikçisi hem de süt alıcı bakımından farklılık olduğu ve Salihli ilçesinde her iki alanda özel sektörün ağırlıklı olduğu saptanmıştır. Bu durum iki ilçenin tedarik zinciri yapısının birbirinden farklı olduğunu göstermektedir. Ancak işletme büyüklüklerine göre yem tedarikçisi ve süt alıcı açısından farklılık saptanmamıştır.

Araştırma sonuçları üreticilerin yem tedariğinde en fazla yem kalitesine önem verdiklerini göstermektedir ve üretici görüşlerine göre en kaliteli yemi mandıra sağlamaktadır. Mandıradan sağlanan yemin kaliteli olmasında mandıraların işletmelerden satın alıp işleyeceği sütün kaliteli olmasına önem vermesi etkilidir. Dolayısıyla mandıralar süt aldığı işletmelere yem satarken bu durumu göz önünde bulundurmaktadır. Fiyat ve ödeme esnekliği kriterleri ikinci ve üçüncü sırada gelmektedir. Tedarikçi tercihi kaliteye göre değerlendirildiğinde mandıra, fiyata göre değerlendirildiğinde kooperatif ve birlik, esnekliğe göre değerlendirildiğinde ise yine mandıra ilk sırayı almaktadır. Üreticilerin yem tercihinde en önemli kriter olarak kaliteyi belirlemiş olmaları, kalite ve esneklik kriteleri çerçevesinde mandıranın avantajlı konumda olması nedeniyle en uygun tedarikçi tercihinin mandıralar olduğu söylenebilir. İşletmeler genelinde üreticilerin \%37.75'i işletmeleri için ihtiyaç duydukları yemi tüccarlardan satın almaktadırlar. Mandıradan satın alanların oranı ise \%31.13'tür. Ödemiş’teki işletmelerde ise mandıradan yem satın alan üreticilerin oranı (\%35.00), tüccarlardan satın alan üreticilerin oranından (\%30.00) fazladır. Bu durum
Ödemiş'teki üreticilerin yem tedarikçi tercihlerinin araştırma sonuçlarıyla uyumlu olduğunu göstermektedir.

Süt satış kriterlerinin öncelik sırası incelendiğinde alıcının süt alım miktarının en önemli kriter olduğu ve sütün tamamını alıp almamasının oldukça önemli olduğu saptanmıştır. Üreticiler sütün tamamını aynı anda satamadıkları takdirde kalan sütü değerlendirebilecek herhangi bir alternatif ya da satın alacak alıcı bulamayacaklarını belirtmişlerdir. Süt satış kriterleri arasında ödeme süresi ikinci, süt fiyatı ise üçüncü sırada yer almaktadır.

Süt alıcı tercihi fiyata ve ödeme süresine göre değerlendirildiğinde doğrudan tüketiciye satış, süt alım miktarına göre değerlendirildiğinde ise kooperatif, birlik, mandıra ve aracıların ilk sırada yer aldığı belirlenmiştir. Üreticiler açısından sütün tamamının alınmasının süt satışında en önemli kriter olduğu dikkate alındığında doğrudan satış alternatifinin uygun bir tercih olmadığı görülmektedir. Bu yüzden en uygun süt alıcı tercihinin belirlenebilmesi için ikinci sırada gelen en iyi alternatif alıcıların değerlendirilmesi gerekmektedir. Kooperatifler fiyata, ödeme süresine ve alım miktarına göre tercihlerde ikinci sırada yer almaktadır. Dolayısıyla üreticilerin süt alıcı tercihini kooperatiflerden yana kullanmaları gerektiği söylenebilir. Oysa mevcut durumda üreticilerin \%42.86'sının mandıralara, \%27.89'unun aracılara ve \%23.81'inin kooperatiflere süt satışı yaptıkları belirlenmiştir. Bu sonuç üreticilerin yem tedarikçi tercihlerinin süt alıcı tercihleri üzerinde daha baskın bir etkiye sahip olduğunu göstermektedir. Çünkü uygulamada genellikle süt toplayıcılar (alıcılar), sütünü aldıkları üreticiye yemi de kendisinden satın alması konusunda zorunluluk getirmektedir. Sermaye açısından güçlü olan üreticiler bu zorunluluğun üstesinden gelebilse de sermaye sıkıntısı yaşayan üreticiler genellikle bu zorunluluğa uymak durumunda kalmaktadırlar. Mandıra ve aracıların üreticilere nakit avans aracılığıyla sermaye desteği sağlayabilme potansiyelinin kooperatiflere göre oldukça fazla olması, üreticilerin süt toplayıcı tercihlerini mandıra ve aracılardan yana kullanmalarında etkilidir. Bu durum elde edilen sonuçların finansal sermayesi güçlü olan üreticilerin işletmeleri için daha uygulanabilir olduğunu göstermektedir. Bu nedenle süt sığırcılığı işletmelerine sağlanan finansal desteklerin artırılması ve üreticilerin örgütlenme düzeylerini artıcı teşviklerin sağlanması gerekmektedir.

\section{KAYNAKLAR}

Anonim (2020) Hayvancılık İstatistikleri. Türkiye İstatistik Kurumu, Ankara. http://www.tuik.gov.tr (Erişim Tarihi: 05/03/2020).

Beikkhakhian Y, Javanmardi M, Karbasian M. Khayambashi B (2015) The Application of ISM Model in Evaluating Agile Suppliers Selection Criteria and Ranking Suppliers Using Fuzzy TOPSIS-AHP Methods. Expert Systems with Applications, 42(15-16): 6224-6236.

Büyüközkan G, Çifçi G (2011) A Novel Fuzzy Multi-Criteria Decision Framework for Sustainable Supplier Selection with Incomplete Information. Computers in Industry, 62(2): 164-174. 
Cheaitou A, Khan SA (2015) An Integrated Supplier Selection and Procurement Planning Model Using Product Predesign and Operational Criteria. International Journal on Interactive Design and Manufacturing, 9(3): 213-224.

Dağdeviren M, Eren T (2001) Tedarikçi Firma Seçiminde Analitik Hiyerarşi Prosesi ve 0-1 Hedef Programlama Yöntemlerinin Kullanılması. Gazi Üniversitesi Mühendislik-Mimarlık Fakültesi Dergisi, 16(2): 41-52.

Demir HH (2010) İmalat Sektöründe Bulanık TOPSIS Yöntemiyle Tedarikçi Seçimi. Yüksek Lisans Tezi, İstanbul Üniversitesi Sosyal Bilimler Enstitüsü, İstanbul.

Ghodsypour SH, O'Brien C (1998) A Decision Support System for Supplier Selection Using an Integrated Analytic Hierarchy Process and Linear Programming. International Journal of Production Economics, 56-57: 199-212.

Güler D, Saner G (2017) Türkiye'de Süt Sığırcılığı İşletmelerinde Tedarik Zinciri Yönetiminin Değerlendirilmesi. Tarım Ekonomisi Dergisi, 23(2): 165-171.

Hamdan S, Cheaitou A (2015) Green Supplier Selection and Order Allocation Using an Integrated Fuzzy TOPSIS, AHP and IP Approach. 5th International Conference on Industrial Engineering and Operations Management, 3-5 March 2015, Dubai/United Arab Emirates.

Handfield R, Walton SV, Sroufe R, Melnyk SA (2002) Applying Environmental Criteria to Supplier Assessment: A Study in the Application of the Analytical Hierarchy Process. European Journal of Operational Research, 141(1): 70-87.

Jeng DJ-F (2015) Generating a Causal Model of Supply Chain Collaboration Using the Fuzzy DEMATEL Technique. Computers and Industrial Engineering, 87:283-295.

Kannan D, Govindan K, Rajendran S, (2015) Fuzzy Axiomatic Design Approach Based Green Supplier Selection: A Case Study from Singapore. Integrating Cleaner Production into Sustainability Strategies, 96:194-208.
Koç G, Uzmay A (2018) Süt Sığırcılığı İşletmelerinde Üreticilerin Kooperatif Kanalıyla Süt Pazarlama Olasılığını Etkileyen Faktörler: Trakya Bölgesi Örneği. Tarım Ekonomisi Dergisi, 24(2): 203-214.

Kokangul A, Susuz Z (2009) Integrated Analytical Hierarch Process and Mathematical Programming to Supplier Selection Problem with Quantity Discount. Applied Mathematical Modelling, 33(3): 1417-1429.

Masella C, Rangone A (2000) A Contingent Approach to the Design of Vendor Selection Systems for Different Types of Co-operative Customer/Supplier Relationships. International Journal of Operations and Production Management, 20(1): 70-84.

Newbold P (1995) Statistics for Business and Economics. Prentice-Hall International. New Jersey.

Nie X (2012) Green Suppliers Selecting Based on Analytic Hierarchy Process for Biotechnology Industry. 2nd International Conference on Information Engineering and Applications, IEA 2012: (Ed. Zhong, Z.), SpringerVerlag, 26-28 October 2012, Chongqing/China.

Noci G (1997) Designing 'Green' Vendor Rating Systems for the Assessment of a Supplier's Environmental Performance. European Journal of Purchasing and Supply Management, 3(2): 103-114.

Özçakar N, Demir HH (2011) Bulanık Topsis Yöntemiyle Tedarikçi Seçimi. i.ü. İşletme Fakültesi İşletme İktisadı Enstitüsü Yönetim Dergisi, 22(69): 25-44.

Saaty TL (1980) The Analytic Hierarchy Process, Planning, Priority Setting, and Resource Allocation. McGrawHill. NewYork.

Saaty TL (2008) Decision Making With The Analytic Hierarchy Process. Int. J. Services Sciences, 1(1): 8398.

Sarı T, Timor M (2015) Tedarikçi Seçiminde ANP, Taguchi ve TOPSIS Yöntemleri ile Otomotiv Sektöründe Bir Uygulama. Kafkas Üniversitesi iiBF Dergisi, 6(10):281300.

Türer S, Ayvaz B, Bayraktar D, Bolat B (2009) Tedarikçi Değerlendirme Süreci İçin Bir Yapay Sinir Ağı Yaklaşımı: Gıda Sektöründe Bir Uygulama. Endüstri Mühendisliği Dergisi, 20(2): 31-40. 